Note

\title{
PARASITOIDS OF Phyllocnistis citrella IN JAGUARIÚNA, STATE OF SÃO PAULO, BRAZIL, BEFORE AND AFTER THE INTRODUCTION OF Ageniaspis citricola ${ }^{1}$
}

\author{
Luiz Alexandre Nogueira de Sá2; Valmir Antonio Costa ${ }^{3}$; Wagner Portes de Oliveira²; Gilberto \\ Ribeiro de Almeida ${ }^{2}$

\footnotetext{
${ }^{2} L a b$. de Quarentena "Costa Lima"- Embrapa Meio Ambiente, C.P. 69 - CEP: 13820-000 - Jaguariúna, SP.

${ }^{3}$ Lab. de Controle Biológico - Instituto Biológico, C.P. 70 - CEP: 13001-970 - Campinas, SP.

*Autor correspondente <lans@cnpma.embrapa.br>
}

\begin{abstract}
The citrus leafminer, Phyllocnistis citrella (Gracillariidae), is among the main pests of citrus in Brazil. The objective of this work was to conduct a survey of parasitoids attacking CLM in Jaguariúna, State of São Paulo, Brazil, before and after the introduction of Ageniaspis citricola (Encyrtidae). Collections of new leaves were made weekly at citrus groves from July-1997 to April-1999. During the survey period, A. citricola was introduced in the area. Before this introduction, Galeopsomyia fausta (Eulophidae) was the predominant species (about $91.83 \%$ of the species composition), but $A$. citricola became predominant after its establishment $(60.10 \%$ against $38.30 \%$ G. fausta). Other parasitoids found were Cirrospilus sp. C (Eulophidae), Horismenus sp. (Eulophidae), Elasmus sp. (Elasmidae), Eupelmus sp. (Eupelmidae) and Conura (Ceratosmicra) sp. (Chalcididae).
\end{abstract}

Key words: leafminer, biological control, parasitoids, citrus

\section{PARASITÓIDES DE Phyllocnistis citrella EM JAGUARIÚNA, ESTADO DE SÃO PAULO, BRASIL, ANTES E DEPOIS DA INTRODUÇÃO DE Ageniaspis citricola}

\begin{abstract}
RESUMO: A larva-minadora-da-folha-dos-citros, Phyllocnistis citrella (Gracillariidae), é atualmente uma praga de importância econômica na citricultura nacional. O objetivo deste trabalho foi identificar o complexo de parasitóides desta praga em Jaguariúna, SP, Brasil, antes e depois da introdução de Ageniaspis citricola (Encyrtidae). Coletas de brotações infestadas pela praga foram realizadas semanalmente, no período de Julho/ 96 a Abril/99. Durante o período do levantamento, A. citricola foi introduzido nesta área. Antes dessa introdução, Galeopsomyia fausta (Eulophidae) era a principal espécie a atacar $P$. citrella $(91,83 \%$ dos parasitóides encontrados), mas $A$. citricola tornou-se predominante após seu estabelecimento na área de liberação $(60,10 \%$ contra $38,30 \%$ de G. fausta). Também outros parasitóides foram encontrados: Cirrospilus sp. C (Eulophidae), Horismenus sp. (Eulophidae), Elasmus sp. (Elasmidae), Eupelmus sp. (Eupelmidae) and Conura (Ceratosmicra) sp. (Chalcididae).

Palavras-chave: larva-minadora-da-folha-dos-citros, controle biológico, parasitóides, citros
\end{abstract}

\section{INTRODUCTION}

The citrus leafminer (CLM), Phyllocnistis citrella Stainton (Lepidoptera: Gracillariidae), was first detected in Brazil in 1996 (Feichtenberger \& Raga, 1996, Gravena, 1996, Prates et al., 1996). Some parasitoid species were found attacking the CLM in Brazil and in some cases achieved high parasitism rates (Perioto 1997, PenteadoDias et al., 1997; Sá \& Costa 1997, Costa et al., 1999). Preliminary results of a survey conducted at Jaguariúna, State of São Paulo, revealed the occurrence of six species of indigenous parasitoids of CLM, with Galeopsomyia fausta LaSalle (Hymenoptera: Eulophidae) the predominant species (Costa et al., 1999).
The objective of this work was to conduct another survey of parasitoids attacking CLM in Jaguariúna, State of São Paulo, Brazil, before and after the introduction of Ageniaspis citricola Logvinovskaya, in a classical biological control program.

\section{MATERIAL AND METHODS}

Leaves were collected weekly at two citrus groves in Jaguariúna, São Paulo, Brazil, from July 1997 to April 1999. The collected leaves were taken to the "Laboratório de Quarentena Costa Lima", at "Embrapa Meio Ambiente", and maintained in cages at $25^{\circ} \mathrm{C}, 80 \pm 5 \%$ relative humidity

1Trabalho apresentado na 5 $5^{\underline{a}}$ International Conference on Pests in Agriculture, Montpellier, France, 1999. 
and a photoperiod of $12 \mathrm{~h}$. Parasitoids were identified using the key of Schauff et al., 1998, and confirmed by Dr. John LaSalle (Unit of Parasitoid Systematics, CABI Bioscience, UK Centre, Ascot). Specimens were deposited in the collection of the "Museu do Laboratório de Quarentena Costa Lima", and in the collection of The Natural History Museum, London, UK.

Constancy were calculated as indicated by Bodenheimer, 1955 (apud Silveira Neto et al., 1976).

\section{RESULTS AND DISCUSSION}

From to July 1997 to April 1999, 13065 P. citrella larvae and pupae were collected from citrus leaves sampled in the Jaguariúna region and $48.70 \%$ of them were parasitized. But during the survey period (in July 1998), Ageniaspis citricola Logvinovskaya (Hymenoptera: Encyrtidae) was introduced into Brazil, comming from USA, through "Laboratório de Quarentena Costa Lima", at "Embrapa Meio Ambiente", in Jaguariúna, in cooperation with the "Fundo de Defesa da Citricultura" (FUNDECITRUS)", "Escola Superior de Agricultura Luiz de Queiroz (ESALQ/USP)" and "Gravena Manejo Ecológico e Controle Biológico de Pragas Agrícolas Ltda. (GRAVENA MANECOL)". In October 1998 this exotic parasitoid was liberated post-quarantine in some citrus orchards in the State of São Paulo including orchards near the area where this survey was carried out, becoming established in January 1999. Thus, there are two distinct periods: before and after the establishment of $A$. citricola.

The first period (July 1997 - December 1998) was characterized by the predominance of $G$. fausta, which accounted for $91.83 \%$ of the parasitoids collected. Other parasitoids found were Cirrospilus sp. C (Hymenoptera: Eulophidae), Horismenus sp. (Hymenoptera: Eulophidae), Elasmus sp. (Hymenoptera: Elasmidae), Eupelmus sp. (Hymenoptera: Eupelmidae) and Conura (Ceratosmicra) sp.
(Hymenoptera: Chalcididae) (TABLE 1). G. fausta and Cirrospilus sp. C were present in 96.85 and $49.61 \%$ of the samples, respectively, while the other species were only incidentally found. All species were collected by Costa et al., 1999.

The situation was greatly modified after the establishment of $A$. citricola in the area, after January 1999 (TABLE 1). This endoparasitoid soon became the predominant species, accounting for $60.10 \%$ of the species composition. The frequency of $G$. fausta and Cirrospilus sp. C was lowered to 38.30 and $1.60 \%$, respectively, while the other parasitoids were not found. Also, $A$. citricola was observed in $84.62 \%$ of the samples. These numbers may indicate a good adaptation of $A$. citricola to the citrus ecosystem of the Jaguariúna region. More studies are needed to precisely evaluate the consequences of $A$. citricola introduction into the State of São Paulo. In the U.S.A. and in Australia, A. citricola was introduced and established with success (Neale et al., 1995 and Hoy et al., $1997 \mathrm{a}, \mathrm{b})$.

In spite of the results obtained after A. citricola introduction, $G$. fausta still is a serious candidate for biological control of the citrus leafminer in this region of Brazil. This species has repeatedly been identified as one of the most important indigenous parasitoids of $P$. citrella in the New World (Cano, 1996; Cano et al., 1996; Castaño et al., 1996: Cave, 1996; Cobo, 1996; de la Llana, 1996; Frias \& Diez, 1996; Martínez, 1996; Ruíz et al., 1997: all as Galeopsomyia sp.).

\section{ACKNOWLEDGMENTS}

This study was granted by "Embrapa Meio Ambiente" and by CNPq (fellowship support). The authors are grateful to Maria Amélia de Toledo Leme and Nilce Chaves Gattaz for the reference review and Roberto A. Alves Pereira for the help in the field. To Dr. Marjorie A. Hoy of the University of Florida, Gainesville, Florida, USA for the help in collecting and exporting the exotic parasitoid Ageniaspis citricola.

TABLE 1 - Relative frequency and constancy of $P$. citrella parasitoids in Jaguariúna, São Paulo, Brazil, before (July 1997 December 1998) and after (January - April 1999) the introduction of $A$. citricola.

\begin{tabular}{|c|c|c|c|c|c|c|}
\hline \multirow[t]{2}{*}{ Parasitoid Species } & \multicolumn{3}{|c|}{ July 1997 - December 1998} & \multicolumn{3}{|c|}{ January - April 1999} \\
\hline & Number & $\begin{array}{c}\text { Relative } \\
\text { Frequency }\end{array}$ & Constancy & Number & $\begin{array}{c}\text { Relative } \\
\text { Frequency }\end{array}$ & Constancy \\
\hline & \multicolumn{4}{|c|}{ - } & \multicolumn{2}{|c|}{ 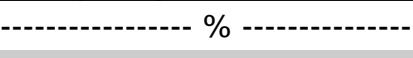 } \\
\hline Galeopsomyia fausta & 2775 & 91.83 & 96.85 & 72 & 38.30 & 92.31 \\
\hline Cirrospilus sp. C & 157 & 5.20 & 49.61 & 3 & 1.60 & 23.08 \\
\hline Horismenus sp. & 62 & 2.05 & 22.05 & 0 & 0.00 & 0.00 \\
\hline Elasmussp. & 26 & 0.86 & 8.66 & 0 & 0.00 & 0.00 \\
\hline Eupelmussp. & 1 & 0.03 & 0.79 & 0 & 0.00 & 0.00 \\
\hline Conura (Ceratosmicra)sp. & 1 & 0.03 & 0.79 & 0 & 0.00 & 0.00 \\
\hline Ageniaspis citricola & - & - & - & 113 & 60.10 & 84.62 \\
\hline
\end{tabular}




\section{REFERENCES}

CANO, E. Phyllocnistis citrella y sus parasitoides nativos en Nicaragua. In: REUNION CENTROAMERICANA SOBRE EL MANEJO INTEGRADO DE PLAGAS DE LOS CITRICOS CON ENFASIS EN MINADOR DE LA HOJA, Managua, 1996. Proceedings. s.l.: s.ed., 1996. 29p.

CANO, E.; LLANA, DE LA A., HERNANDEZ, J.; RUÍZ, F.; PEÑA, J.E.; EVANS, G. Dynamics and biological control of the citrus leafminer in Nicaragua. In: HOY, M. (Ed.) Managing the citrus leafminer. Proceedings. Orlando: University of Florida, 1996. p.76

CASTAÑO, O.; GARCIA, R.F.; TROCHEZ, A.; ROJAS, L.; PEÑA, J.E.; EVANS, G. Biological control of the citrus leafminer, Phyllocnistis citrella, in Colombia. In: HOY, M.A. (Ed.) Managing the citrus leafminer. Proceedings. Orlando: University of Florida, 1996. p.76.

CAVE, R.D. Biological control of citrus leafminer in Honduras. In: HOY, M. (Ed.) Managing the citrus leafminer. Proceedings. Orlando: University of Florida, 1996. p.78.

COBO N.G.M. Ciclo biologico del minador de las hojas de los citricos Phyllocnistis citrella Stainton (Lepidoptera: Gracillariidae) y su relacion con sus hospederos y enemigos naturales en el Valle del Cauca. Palmira, 1996. 158p. Tese (Doutorado) -Universidad Nacional de Colombia.

DE LA LLANA, A. Evaluacion de factores biologicos de mortalidad de Phyllocnistis citrella en Nicaragua. In: REUNION CENTROAMERICANA SOBRE EL MANEJO INTEGRADO DE PLAGAS DE LOS CITRICOS CON ENFASIS MINADOR DE LA HOJA, Managua, 1996. Proceedings. s.l.: s.ed., 1996. 16p.

COSTA, V.A.; SÁ, L.A.N. de; LA SALLE, J.; NARDO, E.A.B. de; ARELLANO, F.L.; FUINI, L.C. Indigenous parasitoids (Hym.: Chalcidoidea) of Phyllocnistis citrella (Lep.:Gracillariidae) in Jaguariúna, São Paulo State, Brazil: preliminary results. Journal of Applied Entomology, v.123, p.237-240, 1999.

FEICHTENBERGER, E.; RAGA, A. First report of Citrus Leafminer Phyllocnistis citrella (Lep.: Gracillariidae) in Brazil. In: REUNIÃO INTERAMERICANA DE HORTICULTURA TROPICAL, 42., Curitiba, 1996. Anais. Curitiba, 1996. p.445.

FRIAS, E.; DIEZ, P. Parasitoides (Eulophidae, Elasmidae) nativos del "minador de las hojas de los citricos" (Phyllocnistis citrella Stainton) (Lep.: Gracillariidae) encontrados en la provincia de Tucuman. Revista de Investigation, v.10, p.59-60, 1996.

GRAVENA, S. Bicho mineiro dos citros. Laranja \& Cia, v.44, p.3-5, 1996.

HOY, M.A.; NGUYEN, R.; POMERINKE, M.A.; BULLOCK R.C.; HALL D.G.; KNAPP J.L.; PEÑA J.E.; BROWNING, H.W.; STANSLY, P.A. Classical biological control of the citrus leafminer. In: FERGUSON, J.G.J.; HOCHMUTH, G.J.; MAYNARD, D.N. (Ed). Florida Agricultural Conference and Trade Show - Citrus and Vegetable. Gainesville, 1997. Proceedings. Fort Myers: University of Florida, 1997a. p.21-25.
HOY, M.A.; NGUYEN, R.; POMERINKE, M.; BULLOCK, R.; HALL, D.; KNAPP, J.; PEÑA, J.; BROWNING, H.; STANSLY, $\mathrm{P}$. Distribution of $A$. citricola: a parasite of the citrus leafminer. Citrus Industry, n.5, p.51-52, 1997b.

MARTÍNEZ-B., C. Insectos parasitoides del minador de la hoja de los citricos, Phyllocnistis citrella Stainton, en tres localidades de la zona centro del estado de Tamaulipas, Mexico. Victoria, 1996. 47p. Tese (Doutorado) - Universidad Autonoma de Tamaulipas.

NEALE, C.; SMITH, D.; BEATTIE, G.A.C.; MILES, M. Importation, host specificity testing, rearing and release of three parasitoids of Phyllocnistis citrella Station (Lepidoptera: Gracillariidae) in Eastern Australia. Journal of the Australian Entomological Society, v.34, p.343-348, 1995.

PENTEADO-DIAS, A.M.; SANTIN, G.; PAIVA, P.E.B.; PINTO, R.A. Parasitóides de Phyllocnistis citrella (Stainton) (Lepidoptera: Gracillariidae: Phyllocnistinae) no Estado de São Paulo. Laranja, v.18, p.79-84, 1997.

PERIOTO, N.W. Primeira ocorrência do gênero Galeopsomyia Girault (Hymenoptera: Chalcidoidea: Eulophidae) para o Brasil. O Biológico, v.59, p.97-98, 1997.

PRATES, H.S.; NAKANO, O.; GRAVENA, S. A minadora das folhas de citros "Phyllocnistis citrella"-Stainton, 1856. Campinas: CATI, 1996. 3p. (Comunicado Técnico, 129)

RUÍZ-C., E.; MATEOS-C., J.R.; CORONADO-B., J.M. Galeopsomyia (Hymenoptera: Eulophidae), parasitoide del minador de la hoja de los citricos, Phyllocnistis citrella Stainton (Lepidoptera: Gracillariidae) en Tamaulipas, Mexico. Folia Entomológica Mexicana, v.96, p.107-108, 1996.

SCHAUFF, M.E.; LASALLE, J.; WIJESEKARA, G.A. The genera of chalcid parasitoids (Hymenoptera: Chalcidoidea) of citrus leafminer Phyllocnistis citrella Stainton (Lepidoptera: Gracillariidae). Journal of Natural History, v.32, p.1001- 1056, 1998.

SÁ, L.A.N. de; COSTA, V.A. Ocorrência de parasitóides de Phyllocnistis citrella no município de Jaguariúna, SP: resultados preliminares. In: CONGRESSO BRASILEIRO DE ENTOMOLOGIA, 16.; ENCONTRO NACIONAL DE FITOSSANITARISTAS, 7., Salvador, 1997. Resumos. Salvador: SEB/CNPMF, 1997. p.145.

SILVEIRA NETO, S.; NAKANO, O.; BARBIN, D.; VILLA-NOVA, N.A. Manual de ecologia dos insetos. São Paulo: Agronômica Ceres, 1976. 419p.

$\overline{\text { Received March }}$ 13, 2000 